\title{
ISLAM AND NATIONAL RESPONSIBILIT'Y*
}

\section{—: 0 :- \\ II. ENGLAND AND HER DEPENDENCIES}

Isram is a political, social and religious problem for every one of the British Dominions in which it exists in any strength. Their policy in regard to it is a matter of national responsibility, and, therefore, the final responsibility for their conduct rests with the Home Government and the people who put them in power. How vast this responsibility is may be perceived from the large number of Moslems under our rule. These are estimated at $22,606,344$ in Africa and $67,871,767$ in Asia. Thus in all we are entrusted with the material, moral and spiritual interests of 90,478,111 Moslems, while only $13,278,800$ remain under the Khalifat in the Oтtoman Empire, and 76,596,219 under all other Western Governments put together.

No believer in God can doubt that there is a Divine Purpose in this, nor can any Christian fail to see that our Lord's words, "Ye shall be witnesses unto Me," impose upon us the duty of evangelising the greater part of the Mohammedan world.

How are we discharging this duty? What is the attitude towards their evangelisation taken by the Government authorities in Asia and Africa, in those extensive regions which owe allegiance to England?

Omitting Egypt and South Africa for the present, we proceed to consider the state of affairs in India, East and East Central Africa, and West Africa.

* This series of articles opened with Miss J. von Meyer's paper on Russia. Maslcm World, April, 1914. 
I. The Moslem population of India, including Ceylon, is about sixty-six millions. Moslems are most numerous in North India, where they form more than half the population of the Punjab, of Bengal and Assam, and of Kashmir, and nearly the whole of that of the North West Frontier Province and of Baluchistan. Almost all Missionary Societies at work in India have men and women engaged in preaching the Gospel to Moslems as well as to others. It is well-known that the Indian Government professes strict religious neutrality, and that it has generously helped education, not only by establishing secular schools and colleges of its own, but also by giving Grants-in-aid to both Christian and Moslem, Hindu and other institutions, in due proportion to the secular work which they do. There are Government as well as Mission hospitals.

Government has given special inducements to Moslems to accept a Western education. Unless in this way, it cannot be said that, except very recently in one instance, any undue encouragement has been afforded to Islam as such.

The instance we refer to is, of course, the Islamia College at Peshawar. This College was opened last year, under the auspices of the Local Government, and the whole weight of that Government was thrown into the scale in its favour by a system of "tied" scholarships attached to it and provided out of public funds. This policy was adopted to the detriment of the Edwardes College, which had for many years done an admittedly excellent work among the youth of the Afghan and frontier tribes, and regarding which a great educational authority has thus borne witness: "Nowhere in India have I seen an Institution where all external features were so eminently adapted to foster the spirit of orderly work, and with it mental and physical cleanness." The Government has gone so far in the way of encouraging a Moslem College in Peshawar in opposition to a Christian one, that it actually gives Rs. 42,000 per annum as a Grant-in-aid to the new Islamia College, and only Rs. 200 a year to the Edwardes College. This conduct is in direct opposition to their professed neutrality in religious 
matters. It is a "Political experiment" which may have far-reaching results, and it has naturally produced far and wide the impression that the Government is hostile to Christianity and strongly in favour of Islam. To produce such an impression is a political blunder of the first magnitude. Such an unfair step should be retraced at once.

II. We now turn to East Africa, including East Central Africa. In Uganda (Buganda) itself the European officials are so favourably impressed by what they have seen of the good results of missionary work that they encourage it. The same thing is true of the outdistricts in general ; the few officials who favour Islam there not being themselves inclined to a Christian so much as to a Moslem moral code. In the whole Uganda diocese there are some 78,000 Moslems out of a population of $3,700,000$. In the Nile Province, recently taken over by the Sudan Government, there are few Moslems as yet, but they are coming in the form of Egyptian officials and Nubian soldiers. As yet, however, the lamentable policy adopted in the Sudan has not been introduced.

In British East Africa the 23,000 Indians are mostly Moslems, and their influence is increasing. All over this Protectorate, even in out-of-the-way places, there are shops kept by Indian Moslems. (The same thing may be said concerning German East Africa.) From the Juba River southwards along the coast there are to be found numbers of Mohammedans, who are especially to be noticed in such places as Gasi, Mombasa, Malindi, Takaungu, Lamu. In the Hinterland of the coast-strip from the Juba to the Tana are Somalis and many Moslem tribesmen. A few villages in the Kenia and Kikuyu highlands are entirely Moslem, while in and around Nairobi are to be found a large number of traders professing Islam. A fairly large part of the adult population in Bokwa and Gedja, north of the Uguru Mountains, is Mohammedan.

The Government of British East Africa seems to aim at conserving Islam wherever it finds that faith. While not actively and officially supporting Islam, the Govern- 
ment-as represented by not a few of its officers-likes to see it supplanting Paganism. At present the Government " appears to put obstacles in the way of all concerned in seeking to evangelise the people of British East Africa." So much has this been the case that not long since the various Missions sent a special Deputation to urge that the Government should at least be neutral, and no longer use its influence to keep the chiefs and others from Christian teaching, nor shew a tendency to encourage Islam as more suitable for the people than Christianity. The Government has gone out of its way to build, open, staff and support schools for Arabs, Suahelis and others, in which no Christian teaching may be given. There are some reasons for hoping, however, that this foolish and unworthy policy will be modified, if not abandoned.

III. In West Africa in general and in Nigeria in particular, the Local English Government has pursued and is still pursuing a line of policy in favour of Islam which is a disgrace to the British nation.

Above all, in Northern Nigeria the Government openly takes the side of Islam and as openly opposes Christian mission work. Moslem teachers are permitted to propagate their religion quite freely wherever they please, while Christian missionaries are in some cases forbidden access even to Pagan tribes. For instance : though the Haüsas are for the most part Moslems, yet it is not generally known that there are among them, living in villages in the Emirates of Kano and Zaria, a considerable number of true Haüsas who have hitherto refused to accept Islam. They are called the Maguzawa, and are not to be confounded with the Pagans of the Bauchi Province, who do not speak Haüsa. Missionaries have been prohibited from access to these Maguzawa, lest on their way thither they should come in contact with Moslem enquirers. This would, in the opinion of the Government, lay the administration open to the charge of allowing a Mission to Moslems, which they say they are pledged not to do! Thus our local Government identifies itself with Islam against Christianity, and actually adopts an attitude towards Christian Missions which 
the Islamic Government of Persia itself no longer ventures to take up. The missionaries are actually afraid to inform the English public of the worst details of the way in which their work is restricted and the Mohammedan religion recognised as patronised by the Government and treated as if it were the established religion of this English Protectorate, lest worse oppression should follow. Yet in the Times some two years ago an Englishman in high position was permitted to urge that no religious instruction except Mohammedan should be allowed in the Government Schools, nor did that journal admit a reply to appear. Hence the Koran is now taught by Moslem teachers in all Government Schools in Mohammedan districts, and Islamic Law is now being introduced and administered in Pagan tribes in Northern Nigeria. This "is worse than a crime ; it is a blunder."

The Yoruba country contains about 2,500,000 people. Till comparatively recently these were practically all Pagan, having resisted the Mohammedan invasion from the North. The chief exception was the city of Ilorin. Islam, however, did not spread much in the Yoruba country till after the British Protectorate was made effective, about A.D. 1893. The "Pax Britannica" has led to Moslem teachers from the North establishing their religion wherever they go. Now nearly every village has its Mosque as well as its Church.

We now come to the Sierra Leone Colony and Protectorate. The former is regarded as nominally Christian, the latter contains a population of about $1,323,151$, perhaps half of whom are Moslems. The Government seems to aim at observing religious neutrality, but evidently prefers, if it must err in the matter at all, to err in favour of Islam. Its general attitude towards Islam has been described as " half fear, half favour," owing probably to a greatly exaggerated idea of the likelihood of a Pan-Islamic movement if Moslem susceptibilities should be excited. It is far easier for the Government to include the Pagans under the head of Mohammedans than to recognise and make provision for so many rude and savage heathen sects; yet, when (as has happened) this feeling leads to the 
prohibition of Christian teaching and the use of the Koran as a text-book in a school for the sons of both heathen and Mohammedan chiefs (on the plea that it is a Moslem, though Government, school), to the appointment of a Moslem chaplain to a regiment of Moslems and heathens mixed, while refusing Christian clergy access to their quarters, or again to the selection of only Mohammedan chiefs for presentation to distinguished visitorsall this is a direct encouragement of Islam on the part of the Government.

We are glad to notice that, whereas from 1900 onward the Government has maintained a number of Moslem schools at the expense of public funds, there is now the prospect of that system being altered. The Government has just begun to make grants-in-aid to Mission schools, but this system is still in its infancy.

A good deal of the attitude of Government towards Islam is due to the utterly mistaken idea that all the people in the Protectorate who are not professing Christians are Moslems. So far is this from being the case that probably half of them are Pagans still. This is true of the Temne and Mandi tribes in particular.

It should be understood that Christian missionaries are not the foes but the friends of Moslems. The Koran itself says, "Of all men ... thou shalt certainly find those to be nearest in affection to them" (i.e., to Moslems), "who say, "We are Christians"" (Sûrah $A l$ Mâidah, 85). The English "Colonial" Governments help the Moslem population in many ways, for instance in giving peace, justice, security for life and property, and secular education, and in preventing oppression and cruelty. But these things are not enough in themselves to make men truly happy, for "Man shall not live by bread alone, but by every word that proceedeth out of the mouth of God." We wish to bring them to the knowledge of Him whom their own Koran acknowledges to be Kalimatu'llâh, "The Word of God." We are their debtors until we give them what we prize most ourselves -spiritual peace, and the knowledge and love of God, concerning which things one highly honoured by all Moslems is reported to have said, $M \hat{a}$ 'arafnâka haqqa 
ma'rifatika, "We have not known Thee as Thou shouldst be known." The truth of this saying will be clear to anyone who compares the following two passages, one from a famous Arabic writer and the other from the Old Testament. Tâju'ddîni's Sulkî writes: "Kun ma" Allâhi ka'lmayvit baina yadai 'lghâsil": "become with God as the corpse before the washer." But Isaiah says : "Thou wilt keep him in perfect peace whose mind is stayed on Thee, because he trusteth in Thee. Trust ye in the Lord for ever: for in the LORD Jehovah is everlasting strength." Man needs this loving trust in God, and Christ alone can give it.

Heathens who receive Christian teaching as well as secular education are outstripping Moslems in India and Uganda. Why then train the rising generation in Nigeria and elsewhere in a system which can at best turn their country into another Morocco, or a Persia, or a Syria? Why refuse to give to Moslems-if they will accept it - the very best thing which England can offer them, the "Gift of God," which is "eternal life, through Jesus Christ our Lord ?"

We thankfully admit that the "Pax Britannica" has made possible the proclamation of the Gospel in some Moslem lands (Egypt, for example), and in a measure even in the Turkish Empire proper. Moreover, not a few large-hearted Christian British civilians and officers (such as Lord Lawrence, Sir H. Edwardes, Sir R. Montgomery, Sir D. Macleod, Generals Lake, Reynell Taylor, and Maclagan, and Colonel Martin, in the Punjab), have by their noble personal influence, conduct and character, opened doors for the entrance of the Gospel among Mohammedans, even in such bigoted places as Peshawar. But there now seems to be in some quarters a tendency to refuse Moslems, such as the Haüsa tribes, the religious liberty to which they have as much right as the heathens around them, and to insist on keeping from them the teaching of Him of whom the Koran speaks so highly. This, in the best interests of the Moslems themselves, we deplore. We demand the restoration of the wise policy pursued in the Punjab first and more recently in the rest of India, and that English " Colonial " Governments 
should be delivered from the blunder that once disgraced in that country the East India Company's rule.

It is surely evident that under no circumstances is the Government of an English Dependency or Protectorate justified in forbidding Christian mission work to be introduced and carried on in the regions committed to their charge. We may grant that the Government should observe religious neutrality as a Government, though its members, if they are Christian men in any true sense, cannot and ought not to try to conceal the fact, but must exercise a decidedly Christian influence in their public as well as in a private capacity. But the Christian Churches of the British Empire and of the United States have a right to demand that, if English local Governments do not help forward the spread of the Gospel, at the very least they should no longer be permitted to oppose it, or to thwart the noble and self-denying efforts of our missionaries, who are devoting their lives to obeying our Divine Lord's last Command, and are doing work which, wherever it has been fairly tested, is acknowledged, even by non-Christians, to have produced the highest mental, moral and spiritual results.

W. St. Clatr Tisdali

(Vicar of St. George's, Deal). 